NBER WORKING PAPER SERIES

\title{
STATE AND LOCAL PREVALENCE OF FIREARMS OWNERSHIP: MEASUREMENT, STRUCTURE, AND TRENDS
}

\author{
Deborah Azrael \\ Philip J. Cook \\ Matthew Miller \\ Working Paper 8570 \\ http://www.nber.org/papers/w8570 \\ NATIONAL BUREAU OF ECONOMIC RESEARCH \\ 1050 Massachusetts Avenue \\ Cambridge, MA 02138 \\ October 2001
}

The authors wish to thank Dr. Huiyun Xiang of the Colorado Department of Public Health and the many BRFSS coordinators who provided us with data and information. David Hemenway and Jens Ludwig offered valuable suggestions on earlier drafts. Our research assistant was Jason Powell. The authors made equal contributions to this article. The views expressed herein are those of the authors and not necessarily those of the National Bureau of Economic Research.

(C) 2001 by Deborah Azrael, Philip J. Cook and Matthew Miller. All rights reserved. Short sections of text, not to exceed two paragraphs, may be quoted without explicit permission provided that full credit, including (C) notice, is given to the source. 
State and Local Prevalence of Firearms Ownership:

Measurement, Structure, and Trends

Deborah Azrael, Philip J. Cook and Matthew Miller

NBER Working Paper No. 8570

October 2001

JEL No. K42

\begin{abstract}
Of the readily computed proxies for the prevalence of gun ownership, one, the percentage of suicides committed with a gun, performs consistently better than the others in cross-section comparisons. It is readily computed for states and counties and has a high degree of validity when tested against surveybased estimates. It also appears valid as a proxy for changes over time in gun prevalence, at least at the regional level. Our analysis of this proxy measure for the period 1979-1997 demonstrates that the geographic structure of gun ownership has been highly stable. That structure is closely linked to rural tradition. There is, however, some tendency toward homogenization over this period, with highprevalence states trending down and low-prevalence states trending up.
\end{abstract}

Deborah Azrael

Department of Health Policy and Management

Harvard School of Public Health

677 Huntington Avenue

Boston, MA 02115

azrael@hsph.harvard.edu

Matthew Miller

Department of Health Policy and Management

Harvard School of Public Health

677 Huntington Avenue

Boston, MA 02115

mmiller@hsph.harvard.edu
Philip J.Cook

Sanford Institute of Public Policy

Duke University

Durham, NC 27708-0245

and NBER

cook@pps.duke.edu 
About 40\% of America's households own at least one firearm. The prevalence of ownership differs widely by region, ranging from $25 \%$ in the Northeast and 35\% in the Pacific states, to 60\% in the East South Central region. ${ }^{1}$ Just where a particular state or city falls along this wide spectrum may have a variety of consequences for crime and public health. The probability that a gun is available for immediate use for a suicide attempt, escalating an episode of family violence, or self-defense against an intruder is greater in areas where gun ownership is common than areas where it is less usual. But while firearms prevalence influences availability for these uses, there is no scientific consensus on the ultimate consequences of gun prevalence for suicide, homicide and crime rates.

A systematic analysis of the effects of gun prevalence requires a valid measure of gun prevalence. Prevalence cannot be accurately measured from administrative records, since most states do not require registration or licensing, and compliance is poor in those that do. When available, surveys are a more promising source of data on gun prevalence. A number of national surveys have provided such estimates, but national surveys are not designed to support reliable estimates at the state or local level. While there are occasional state or local surveys with gunownership items, they provide only spotty coverage and are in any event not entirely comparable due to differences in survey method, response rate, and wording of items.

The remaining possibility for analyzing the effects of gun prevalence is use of a good proxy that is consistently available at the desired level of aggregation. Finding a valid and reliable proxy is an old problem (Cook 1979), and a number of alternatives have been proposed and utilized, generally in rather ad hoc fashion.

In this paper we analyze several plausible proxies for gun prevalence for which the data are readily available at the state and county level over a number of years. We find that among these is a simple measure that "performs" as well or better than the rest; namely, the percentage of suicides committed with a firearm. After validating this measure, we use it to describe the geographic structure of gun prevalence, documenting the wide differences among states and the remarkable stability of these differences over recent decades. We further demonstrate that this stable structure is becoming "flatter" over time, with a trend toward greater geographic homogeneity.

That this proxy performs well in the cross section is no guarantee that it also tracks trends in gun prevalence. However, we find it does track

\footnotetext{
${ }^{1}$ These statistics are computed from the General Social Survey, 1998.
} 
intertemporal variation in regional gun prevalence over the period 1980 to 1998.

\section{Survey Estimates of Firearms Prevalence}

Surveys provide the only useful direct estimates of the prevalence of gun ownership. Most states lack any sort of registration or licensing requirement for gun owners. Even in the handful of states that do have such a requirement in place, the resulting administrative records provide little useful information on the number of gun owners; such records are typically incomplete (due to lack of compliance), out of date, and difficult to access. Survey data fill this gap, but only to a limited extent.

The "gold standard" for national surveys of gun ownership is the General Social Survey, conducted by the National Opinion Research Center most years from 1972 to 1993 and biennially since 1994 (Davis and Smith 1998). In its current form the GSS is conducted in person with a national area-probability sample of 3,000 non-institutionalized adults. The response rate has been quite high (for example, $78 \%$ in 1994, $76 \%$ in 1996, 76\% in 1998). Its sample is chosen to be representative of the nation and of each of the nine Census regions, but not of individual states.

Two other readily available survey sources provide some information on the prevalence of gun ownership at the state level. First, between 1992 and 1995 the Behavioral Risk Factor Surveillance System (BRFSS) included gun-ownership items in surveys conducted in 21 states (Powell et al., 1998). These surveys were conducted under the auspices of state health departments using the random-digit-dial telephone technique. The median sample size of adults ages 18 and over was 2,061, and the median response rate was $67 \% .{ }^{2}$

Second, two national surveys conducted on behalf of the Harvard Injury Control Research Center (HICRC) provide the basis for state-level estimates. These surveys were conducted by using the random-digitdial technique in 1996 and 1999, with sample sizes of 1,900 and 2,500 respectively. States were sampled in proportion to their population relative to that of the United States, producing valid estimates of statelevel household gun ownership, albeit with small sample sizes. Detailed information on these surveys has been published previously (Powell et al.

\footnotetext{
2 The median proportion of homes with telephones was $95.6 \%$, and the median refusal rate for the firearm section was $2.0 \%$. For states that asked firearm questions in more than one year, the most recent data were used.
} 
1998; Azrael and Hemenway 2000; Miller, Azrael, and Hemenway 2000; Hemenway, Azrael, and Miller 2000).

"Prevalence" may be usefully defined with respect to individuals or households, and with respect to all types of guns or just handguns. ${ }^{3}$ (Handguns are of particular interest because they are vastly over represented in crime in comparison with long guns.) The GSS provides enough detail in recent years to estimate all four variants: the percent of households with some type of gun, the percent of households with a handgun, the percent of adult individuals who possess a gun, and the percent of adult individuals who possess a handgun. These four prevalence measures are highly correlated across the nine Census regions. As shown in Table 1, the inter-region correlations are in every case above 90\% (based on estimates from the GSS for 1994, 1996, and 1998 combined). Hence a proxy that provides a valid approximation to the geographic structure of, say, household handgun prevalence, likely also provides a valid approximation of other measures of prevalence. On the other hand, the four measures have followed somewhat different trajectories over time at the national level. ${ }^{4}$

\section{Alternative Proxy Measures}

When survey-based estimates or other direct estimates of gun availability have not been available, social scientists have used proxy measures. Perhaps the first proxy employed in the social-science literature was the fraction of criminal homicides committed with a gun; Brearley (1932) utilized this measure in analyzing the effect of gun ownership on interstate patterns of homicide. Since then it has been used to study the effect of gun availability on homicide rates over time (Fisher, 1976) and across nations (Etzioni and Remp, 1973; Curtis 1974).

Cook (1979) proposed and validated a related measure, namely the average of the gun percent in homicide and with the gun percent in suicide, demonstrating its application in a study of city robbery rates; other analysts have utilized this "Cook Index" as well (Miller, Azrael, and Hemenway 2001; Sloan 1990; Lester 1985). Kleck and Patterson (1993) have offered the most-elaborate proxy, a 5-item factor computed from the percentage gun use in homicide, suicide, assault, and robbery, as well as

\footnotetext{
3 The "handgun" category includes pistols and revolvers, while the long-gun category includes rifles and shotguns. While handguns make up only about one-third of the total guns in private hands, they account for over $80 \%$ of gun crimes and injuries (Cook 1991).

${ }^{4}$ Since 1980 the household gun prevalence in the United States has trended down, while the prevalence of individual ownership has been close to constant. The explanation for the difference in trends is in the downward trend in the size of households, and in particular the percentage of households that include a man.
} 
the value of stolen guns relative to the total property stolen. These and other studies that utilized proxies computed from crime statistics and mortality statistics are summarized in Kleck (1997, pp. 260-261).

An alternative source of proxy measures is statistical information on participation in gun-related activities. Krug (1968), for example, utilized data on the rate of hunting licenses issued per capita. Recently a prominent study made use of county-level subscription rates to Guns \& Ammo (Duggan, in press), a magazine oriented to handgun users.

In what follows, we do not attempt an exhaustive analysis of possible proxies, but focus on two types: those based on Vital Statistics-Mortality data, and those based on subscription and membership information. The Vital Statistics data have the virtues of being consistent across time and space, of high quality, and readily available for annual estimates at the national, state, or county level (though only counties with large populations are identified in the public-use data files). We also assess measures based on subscription data for Guns \& Ammo, and on membership information for the National Rifle Association; these data are available for a number of years at the county level.

The specific list of proxy measures is as follows:

FS/S Firearms suicides divided by suicides, 1995-97

FH/H Firearms homicides divided by homicides, 1995-97

Cook The average of $\mathrm{FS} / \mathrm{S}$ and $\mathrm{FH} / \mathrm{H}$

UFDR Death rate per 100,000 due to unintentional injury from firearm

G\&A Subscriptions to Guns \& Ammo Magazine per capita, 1996

NRA NRA members per capita, 1996

Appendix tables A1 and A2 provide descriptive statistics and source information.

These measures are for the most part positively correlated with each other, as shown in Table 2. The correlation between NRA (National Rifle Association membership) and G\&A (subscription rate for Guns \& Ammo

\footnotetext{
5 Various refinements of each of these measures are possible and reasonable. For example, it seems likely that the weapons used in killings of adults may be more representative of household prevalence than killings of adolescents. It also may seem reasonable to standardize the measures with respect to demographic characteristics; for example, women may be less likely to make use of a gun in the house to commit suicide than men, in which case a proxy based on the gun percent in suicide would be affected by the gender mix. In practice, we find that such refinements tend to make little difference in the validity studies we report.
} 
Magazine) is $90 \% .{ }^{6} \mathrm{FS} / \mathrm{S}$ (the gun fraction in suicide) is highly correlated with UFDR (73\%) but less so with FH/H (just 37\%). Correlations between NRA and mortality measures are low or even negative: .35 (FS/S), -.19 (FH/H), .55 (UFDR). Thus these proxies are not interchangeable.

\section{Evaluation of the Proxy Measures}

The validity of these proxy measures can be evaluated by comparing them with survey data. (See Appendix Table A3 for descriptive statistics and source information.) We note that the survey data are subject to sampling error, which may be quite large for small states, and to both response and non-response errors. But they provide the only direct measure of gun prevalence.

This comparison produces a clear winner, as shown in Table 3:

- FS/S has the highest correlation with survey-based estimates of household prevalence for all three sources of survey data. The correlation coefficient is $90 \%$ across the 21 BRFSS states, and not much lower (81\%) across the contiguous 48 states using the HICRC surveys, despite the large sampling errors for the smaller states in those surveys.

- On the other hand, $\mathrm{FH} / \mathrm{H}$ performs poorly in the cross-state analysis, and combining it with FS/S (the Cook index) is not as good as simply using FS/S by itself.

- UFDR performs well enough but not as well as FS/S, and in any event is based on such a relatively rare event (unintentional shooting death) as to render it useless for small-area estimates.

- NRA membership and the G\&A subscription rate are also dominated by FS/S in these comparisons, and in the regional comparisons appear worthless.

We conclude that FS/S is a superior proxy measure for cross-section analysis, easily computed from available data for state and larger local jurisdictions and valid against survey-based estimates.

FS/S can also be calculated for counties and other sub-state levels from readily available mortality statistics. To explore the performance of FS/S as a sub-state proxy of firearm ownership we needed to identify states for which sub-state firearm ownership estimates were available. Few states, however, have such estimates. Of the 21 states that included the

\footnotetext{
${ }^{6}$ We also experimented with the subscription rates for American Rifleman and American Hunter. The interstate correlation with NRA is $97 \%$ for each of them. Presumably it is so high because a subscription to one of these magazines is a benefit of NRA membership.
} 
firearms module in the BRFSS only one state, Colorado, was able to provide us with sub-state survey estimates of household firearms ownership that corresponded to geographic units for which we could calculate FS/S. ${ }^{7}$ Colorado collected firearm-ownership estimates (and mortality data) for 12 of the state's 14 Planning and Management Regions (PMRs) in 1996. The 14 PMRs are a partition of the state's counties. Colorado did not estimate household firearm ownership rates for 2 of the 14 PMRs because sample sizes from these 2 PMRS contained too few people $(\mathrm{N}<50)$. For the 12 PMRs for which household firearm estimates were available (median sample size $=416$, ranging from 57 to 2,752 ) the correlation between FS/S and survey estimates of firearm ownership rates was 0.75 (unweighted). Weighting by sample size increased the correlation to 0.87 .

\section{Estimation of Gun Prevalence from FS/S}

The household or individual prevalence of guns in a particular jurisdiction can be estimated from knowledge of FS/S for that jurisdiction. As it turns out, there is a linear (but not proportional) relationship between FS/S and prevalence over the relevant range. Equations for doing the conversion from proxy value to prevalence estimate are presented below. In order to correct for heteroskedasticity due to sampling error in the surveys, these regression equations are estimated using weighted least squares (WLS), with weights equal to the square root of the sample size for each jurisdiction. The weights take account of the fact that the survey-based prevalence estimates are much more precise in some states than others, given that the smaller states have sample sizes as low as 7.

To begin, Figure 1 depicts a scatterplot of state-level prevalence estimates (from BRFSS) against FS/S. The WLS line is superimposed. Note that the linear fit appears quite good for the range that we observe, even though the underlying relationship must be curvilinear at the endpoints (since the gun prevalence must lie between 0 and 1). Also plotted in Figure 1 are the BRFSS estimates for the household prevalence of handguns, which unfortunately are only available for 10 states.

\section{Reference: Figure 1}

Figure 2 depicts a scatterplot of region-level GSS estimates for household and individual prevalence of both firearms and handguns, all plotted against FS/S. The four WLS lines are superimposed. The "fit" is excellent in every case.

${ }^{7}$ Alaska, the only other state that could provide sub-state geographic estimates, could only provide these estimates for four geographic areas. 
Reference: Figure 2

Table 4 provides coefficient estimates and statistics on "fit" for these and other WLS regression lines depicted in Figures 1 and 2. It also reports the equation for the regression of household prevalence (estimated from the HICRC surveys) against FS/S across the contiguous 48 states.

As shown in Table 4, there are three equations for estimating household prevalence of firearms, based on quite different sources - GSS for 9 regions, BRFSS surveys for 21 states, and HICRC surveys for 48 states. The three equations are remarkably similar, particularly with respect to the slope coefficient, which is in every case close to 1.0 (implying a oneto-one relationship between household prevalence percentage and gun percentage in suicide).

Appendix Table A4 provides survey-based prevalence estimates for each state together with the fitted values. The largest disparities, unsurprisingly, show up in the states with small survey sample sizes.

\section{The Geographic Structure of Gun Ownership}

The prevalence of gun ownership has a strong regional pattern, with relatively low rates in the Northeast and Pacific Coast, and high rates in the South and Mountain states. This geographic pattern has been quite stable over time, suggesting that the determinants of gun prevalence have more to do with tradition, culture and childhood experience than with concern about crime or other relatively volatile matters. ${ }^{8}$

To explore the evolution of interstate patterns over time, FS/S was calculated for all 50 states and District of Columbia for each of three different periods. As shown in Table 5, over a 19-year interval the pattern remained essentially unchanged: the correlation across the states between the earliest period (1979-81) and the most recent (199597) is $95 \%$.

What underlies this structure? The answer, to a large extent, is rural tradition (Cook and Ludwig 1996). The percent of the state's population that was rural in 1950 is highly correlated (across states) with household gun ownership over four decades later: the correlation with FS/S is $80 \%$

8 Cook and Ludwig (1996) found that $80 \%$ of adult gun owners had grown up in a household with guns. 
(for the years 1994, 1996, and 1998 combined), and is almost as high for the survey-based estimates. ${ }^{9}$

Nonetheless, this geographic structure is not immutable. In fact, there is a pronounced tendency of increasing homogeneity. When the states are sorted by 1987-9 values (to avoid regression to the mean), then 13 of the bottom 15 have increased between 1980 and 1996, while all 15 of the highest have decreased. Measures of dispersion tell the same story: From 1980 to 1996, the interquartile range declined from $45 \%$ to $37 \%$, while the interdecile range declined from $50 \%$ to $42 \% .{ }^{10}$

\section{The Validity of FS/S over time}

Although the results presented above demonstrate that FS/S is a valid proxy for cross-section variation, it is not necessarily true that it is also valid as a proxy for variation. It is possible, for example, that trends in weapon preferences by suicidal individuals, or in the demographic composition of suicide, create a shifting relationship between gun availability and weapon choice.

To explore the validity of FS/S as a proxy for changes in gun-ownership prevalence over time, we once again use data from the General Social Survey. It has included identical items on gun ownership for 14 of the years between 1980 and 1998. As noted above, the GSS sample is designed to be representative at the level of the Census region. Thus it is possible to estimate gun prevalence for a panel of the nine regions by year with only a few gaps. We construct such a panel for the four measures of gun ownership: Individual gun and handgun ownership, and household gun and handgun ownership.

Table 6 reports the results of regressing each of the four measures against FS/S. All regressions include regional fixed effects, so the coefficient estimates on FS/S reflect only inter-temporal covariance with gun ownership.

FS/S performs well in these trials. The coefficients are in each case more than twice the standard error, and perhaps more impressive, very similar to those estimated from cross-section data on states (reported in Table 4), as seen below:

\footnotetext{
9 The correlation across 48 states between "percent rural in 1950" and household gun prevalence estimated from the HICRC survey is $74 \%$; the correlation across 21 states using the BRFSS data is $79 \%$.

${ }^{10}$ Details available from the authors on request. We have not attempted to explore the reasons for increasing homogeneity. It may reflect increased immigration and interstate migration.
} 


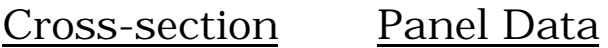

$\begin{array}{lcc}\text { Household gun } & .97 & .91 \\ \text { Individual gun } & .73 & .81 \\ \text { Household handgun } & .78 & .74 \\ \text { Individual handgun } & .55 & .55\end{array}$

We conclude that FS/S is a useful proxy for gun prevalence for intertemporal variation, at least at the level of the Census region. Over time, as across states, a one percentage point increase in FS/S is associated with a one percentage point increase in household prevalence of gun ownership.

Appendix Table A5 elaborates on this validation test, presenting the results of other regression specifications, and also includes a direct comparison with another proxy, the subscription rate for Guns \& Ammo. ${ }^{11} \mathrm{FS} / \mathrm{S}$ outperforms the other proxy in every test.

\section{Conclusion}

Of the readily computed proxies for the prevalence of gun ownership, one, the percentage of suicides committed with a gun, performs consistently better than the others in cross-section comparisons. It is readily computed for states and counties and has a high degree of validity when tested against survey-based estimates.

FS/S also appears valid as a proxy for changes over time in gun prevalence, at least at the regional level.

Our analysis of this proxy measure for the period 1979-1997 demonstrates that the geographic structure of gun ownership has been highly stable. That structure is closely linked to rural tradition. There is, however, some tendency toward homogenization over this period, with high-prevalence states trending down and low-prevalence states trending up.

\footnotetext{
11 Duggan (in press ) utilizes the Guns \& Ammo subscription rate as his proxy for gun prevalence. His demonstration of its validity for inter-temporal variation is based primarily on a set of regressions similar to those presented in Table A5, but using statelevel data. As he notes, the General Social Surveys do not provide representative samples at the state level. For that reason our replication of Duggan's validity test uses the GSS data for regional estimates only.
} 
We conclude that FS/S provides the best of the readily computed proxies for analyzing the influence of gun prevalence on gun use in criminal violence and suicide. 


\section{REFERENCES}

Azrael, Deborah and David Hemenway. 2000. "In the Safety of Your Own Home: Results from a National Survey on Gun Use at Home." Social Science \& Medicine 50(2), 285-291.

Brearley, Harrington C. 1932. Homicide in the U.S. Chapel Hill: University of North Carolina Press.

Cook, Philip J. 1979. "The Effect of Gun Availability on Robbery and Robbery Murder: A Cross Section Study of Fifty Cities." In Policy Studies Review Annual, vol. 3, edited by Robert H. Haveman and B. Bruce Zellner. Beverly Hill, CA: Sage.

Cook, Philip J. and Jens Ludwig. 1996. Guns in America: Results of a Comprehensive National Survey on Firearms Ownership and Use Washington, D.C.: The Police Foundation.

Curtis 1974. Criminal Violence. Lexington, MA: Lexington.

Davis James A. and Tom W. Smith. 1998. General Social surveys, 19721998 [machine-readable data file]/ Principal Investigator James A. Davis; Director and Co-Principal Investigator, Tom W. Smith; Sponsored by National Science foundation. - -NORC ed. - - Chicago: National Opinion Research Center [producer]; Storrs, CT: The Roper Center for Public Opinion Research, University of Connecticut [distributor].

Duggan, Mark. In press. "More Guns, More Crime. Journal of Political Economy.

Etzioni, Amitai and Richard Remp 1973. Technological Shortcuts in Social Change. New York: Russell Sage.

Fisher, Joseph. 1976. "Homicide in Detroit: The Role of Firearms." Criminology 13:387-400.

Hemenway, David, Deborah Azrael, and Matthew Miller. 2000. "Gun Use in the United States: Results from Two National Surveys." Injury Prevention 6:263-267

Kleck, Gary. 1997. Targeting Guns: Firearms and Their Control. New York: Aldine de Gruyter. 
Kleck, Gary and E. Britt Patterson. 1993. "The Impact of Gun Control and Gun Ownership Levels on Violence Rates." Journal of Quantitative Criminology 9: 249-288.

Krug, Alan S. 1968. "The Relationship between Firearms Ownership and Crime Rates: A Statistical Analysis." Congressional Record (January 30): H570-72.

Lester, David. 1985. "The Use of Firearms in Violent Crime." Crime and Justice. 8: 115-120.

Miller, Matthew, Deborah Azrael, and David Hemenway. 2000.

"Community Firearms and Community Fear." Epidemiology. 11:709714.

Miller, Matthew, Deborah Azrael, and David Hemenway. 2001. "Firearm Availability and Unintentional Firearm Deaths." Accident Analysis and Prevention." 33:477-484.

Powell Kenneth E., Beth C. Jacklin, David E. Nelson, and Shayne Bland. 1998. "State estimates of household exposure to firearms, loaded firearms, and handguns, 1991 through 1995." Am J Public Health. 88(6):969-72.

Sloan, John H., Arthur L. Kellermann, Donald T. Reay, James A. Ferris, Thomas Koepsell, Frederick P. Rivara, Charles Rice, Laurel Gray, James LaGerfo. 1990. "Handgun Regulations, Crime, Assaults and Homicide." New England Journal of Medicine. 319:1256-62. 


\section{TABLES AND FIGURES}

Table 1

Alternative Definitions of Gun "Prevalence"

Correlation Coefficients Across 9 Census Regions

GSS estimates from 1994,1996, 1998 combined

\begin{tabular}{|c|c|c|c|}
\hline & $\begin{array}{c}\text { Household } \\
\text { Gun }\end{array}$ & $\begin{array}{c}\text { Household } \\
\text { Handgun }\end{array}$ & $\begin{array}{c}\text { Individual } \\
\text { Gun }\end{array}$ \\
\hline $\begin{array}{c}\text { Household } \\
\text { Handgun }\end{array}$ & .93 & 1.00 & \\
\hline $\begin{array}{c}\text { Individual } \\
\text { Gun }\end{array}$ & .97 & .91 & 1.00 \\
\hline $\begin{array}{c}\text { Individual } \\
\text { Handgun }\end{array}$ & .92 & .98 & .94 \\
\hline
\end{tabular}

Source: Gun prevalence estimates from NORC General Social Survey, unpublished data

Table 2

Correlation Matrix for Proxy Variables

50 States

\begin{tabular}{|l|l|l|l|l|l|}
\hline Proxy & FS/S & FH/H & Cook & UFDR & G\&A \\
\hline FH/H & 0.37 & & & & \\
\hline Cook & 0.88 & 0.78 & & & \\
\hline UFDR & 0.73 & 0.34 & 0.67 & & \\
\hline G\&A & 0.44 & -0.13 & 0.23 & 0.43 & \\
\hline NRA & 0.35 & -0.14 & 0.17 & 0.35 & 0.90 \\
\hline
\end{tabular}

Source: See text 
Table 3

Validity of Proxies for Household Gun Prevalence

Correlation Coefficients

\begin{tabular}{|c|c|c|c|}
\hline & $\begin{array}{c}\text { HICRC } \\
\mathrm{N}=48 \text { States }\end{array}$ & $\begin{array}{c}\text { BRFSS } \\
\mathrm{N}=21 \text { States }\end{array}$ & $\begin{array}{c}\text { GSS }^{\mathrm{a}} \\
\mathrm{N}=9 \text { Regions }\end{array}$ \\
\hline $\mathrm{FS} / \mathrm{S}$ & 0.81 & 0.90 & 0.93 \\
\hline $\mathrm{FH} / \mathrm{H}$ & 0.02 & 0.19 & 0.52 \\
\hline $\mathrm{COOK}$ & 0.52 & 0.77 & 0.88 \\
\hline UFDR & 0.61 & 0.68 & 0.85 \\
\hline G\&A & 0.75 & 0.67 & 0.51 \\
\hline NRA & 0.67 & 0.55 & -0.06 \\
\hline
\end{tabular}

aGSS prevalence estimates are here based on pooled data from 1994,1996 , and 1998.

Source: See text 
Table 4

Predicting Gun Prevalence from FS/S

Weighted Least Squares Regression Results

\begin{tabular}{|c|c|c|c|c|c|}
\hline Data & $\begin{array}{l}\text { Intercept } \\
\text { (SE) }\end{array}$ & $\begin{array}{c}\text { Coefficient } \\
\text { on FS/S } \\
\text { (SE) }\end{array}$ & $\begin{array}{l}\mathrm{R}^{2} / \mathrm{Adj}- \\
\mathrm{R}^{2}\end{array}$ & SEE & $\begin{array}{l}\text { Number of } \\
\text { Observations }\end{array}$ \\
\hline $\begin{array}{c}\text { HICRC } \\
\text { Household }\end{array}$ & $\begin{array}{l}-0.145 \\
(0.045)\end{array}$ & $\begin{array}{c}0.980 \\
(0.078)\end{array}$ & $.78 / .77$ & 0.063 & 48 States \\
\hline $\begin{array}{c}\text { BRFSS } \\
\text { Household }\end{array}$ & $\begin{array}{l}-0.202 \\
(0.060)\end{array}$ & $\begin{array}{c}1.018 \\
(0.109)\end{array}$ & $.82 / .81$ & 0.060 & 21 States \\
\hline $\begin{array}{c}\text { GSS }^{\text {G }} \\
\text { Household }\end{array}$ & $\begin{array}{l}-0.172 \\
(0.083)\end{array}$ & $\begin{array}{c}0.968 \\
(0.142)\end{array}$ & $.87 / .85$ & 0.038 & 9 Regions \\
\hline $\begin{array}{c}\text { GSS }^{a} \\
\text { Individual }\end{array}$ & $\begin{array}{l}-0.178 \\
(0.048)\end{array}$ & $\begin{array}{c}0.730 \\
(0.082)\end{array}$ & $.92 / .91$ & .021 & 9 regions \\
\hline $\begin{array}{l}\text { GSSa } \\
\text { Household } \\
\text { (handgun) }\end{array}$ & $\begin{array}{l}-0.229 \\
(0.046)\end{array}$ & $\begin{array}{c}0.781 \\
(0.079)\end{array}$ & $.93 / .93$ & 0.021 & 9 regions \\
\hline $\begin{array}{c}\text { GSSa } \\
\text { Individual } \\
\text { (handgun) }\end{array}$ & $\begin{array}{l}-0.180 \\
(0.026)\end{array}$ & $\begin{array}{l}0.554 \\
(.046)\end{array}$ & $.96 / .95$ & 0.012 & 9 regions \\
\hline
\end{tabular}

a 1996 data only.

Source: See text 
Table 5

Stability of Cross-Section Structure of Gun Ownership (FS/S)

Correlation Coefficients

50 states

\begin{tabular}{|c|c|c|}
\hline Period & $1995-97$ & $1987-9$ \\
\hline $1987-9$ & .0 .97 & 0.97 \\
\hline $1979-81$ & 0.94 & \\
\hline
\end{tabular}

Source: State suicide statistics from Vital Statistics Mortality data 
Table 6

Inter-Temporal Validity of FS/S relative to measures of gun ownership GSS Panel data, 1980-1998, for 9 Census regions

Regression coefficients and standard errors

\begin{tabular}{|l|l|l|l|l|}
\hline & $\begin{array}{l}\text { Individual } \\
\text { Ownership } \\
\text { Prevalence }\end{array}$ & $\begin{array}{l}\text { Individual } \\
\text { Ownership } \\
\text { Prevalence } \\
\text { (handgun) }\end{array}$ & $\begin{array}{l}\text { Household } \\
\text { Ownership } \\
\text { Prevalence }\end{array}$ & $\begin{array}{l}\text { Household } \\
\text { Ownership } \\
\text { Prevalence } \\
\text { (handgun) }\end{array}$ \\
\hline $\begin{array}{l}\text { FS/S } \\
\text { coefficient } \\
\text { (Standard Error) }\end{array}$ & $\begin{array}{l}.812^{\mathrm{a}} \\
(.285)\end{array}$ & $\begin{array}{l}.554^{\mathrm{a}} \\
(.201)\end{array}$ & $\begin{array}{l}.905^{\mathrm{a}} \\
(.355)\end{array}$ & $\begin{array}{l}.742^{\mathrm{a}} \\
(.246)\end{array}$ \\
\hline
\end{tabular}

a. Significantly different from zero at the $1 \%$ level

Notes: Each cell contains the key coefficient estimate and SE from a different regression. Each regression includes regional dummies; the coefficients are not reported in this table. $\mathrm{N}=126$, annual observations for the following 14 years: 1980-1982, 1984-1985, 1987-1991, 19931994, 1996, and 1998. (The GSS was not fielded or did not include the relevant items during the missing years.)

$\mathrm{FS} / \mathrm{S}=\%$ of suicides in region committed with a gun, from Vital Statistics data 
Table A1

Proxies from Vital Statistics Mortality Data 50 States, 1995-97

\begin{tabular}{|c|c|c|c|}
\hline Proxy & Definition & $\begin{array}{c}\text { Minimum \# of } \\
\text { events* }\end{array}$ & $\begin{array}{c}\text { Maximum \# of } \\
\text { events }\end{array}$ \\
\hline $\mathrm{FS} / \mathrm{S}$ & $\begin{array}{c}\text { Firearm suicides } \\
\text { divided by } \\
\text { Suicides }\end{array}$ & 109 & 10,519 \\
\hline $\mathrm{FH} / \mathrm{H}$ & $\begin{array}{c}\text { Firearm } \\
\text { homicides } \\
\text { divided by } \\
\text { Homicides }\end{array}$ & 31 & 9,209 \\
\hline UFDR & $\begin{array}{l}\text { Unintentional } \\
\text { injury deaths by } \\
\text { firearm }\end{array}$ & 0 & 333 \\
\hline
\end{tabular}

*Least number of suicides, homicides or unintentional deaths across the 50 states for the indicated period

Table A2

Proxies from Subscription and Membership Data

50 States, 1996

\begin{tabular}{|c|c|c|c|}
\hline Proxy & Definition & $\begin{array}{c}\text { Minimum \# of } \\
\text { subscriptions* }\end{array}$ & $\begin{array}{c}\text { Maximum \# of } \\
\text { subscriptions }\end{array}$ \\
\hline G\&A & $\begin{array}{c}\text { Subscriptions to } \\
\text { Guns \& Ammo } \\
\text { Magazine per } \\
\text { capita }\end{array}$ & 1,388 & 59,729 \\
\hline NRA & $\begin{array}{c}\text { NRA members } \\
\text { per capita }\end{array}$ & 6,250 & 224,753 \\
\hline
\end{tabular}

*Least number of subscriptions across 50 states for 1996 
Table A3

Definitions and Characteristics of Survey-Based Estimates of Prevalence of Gun Ownership

\begin{tabular}{|c|c|c|c|c|}
\hline Survey & Definition and Source & $\begin{array}{l}\text { Jurisdicti } \\
\text { ons }\end{array}$ & $\begin{array}{c}\text { \# obs. } \\
\text { Smallest }\end{array}$ & $\begin{array}{l}\text { \# obs. } \\
\text { Largest }\end{array}$ \\
\hline HICRC* & $\begin{array}{c}\text { HICRC RDD Survey } \\
1996 \& 1999 \\
\text { combined } \\
\end{array}$ & 48 states & 7 & 517 \\
\hline BRFSS** & $1990 \mathrm{~s}$ & 21 states & & \\
\hline GSS*** & 1996 & $\begin{array}{l}9 \text { Census } \\
\text { regions }\end{array}$ & 101 & 353 \\
\hline $\mathrm{GSS}^{* * *}$ & $\begin{array}{c}1994,1996,1998 \\
\text { combined }\end{array}$ & $\begin{array}{l}9 \text { Census } \\
\text { regions }\end{array}$ & 288 & 1087 \\
\hline
\end{tabular}

* Data come from a national random-digit-dial (RDD) telephone survey, conducted by Fact Finders, Inc., a social science survey firm, in $1996(n=1900)$ and again in $1999(n=2500)$. The sample is representative of United States households with telephones. (These surveys are described in detail in Hemenway, Azrael, Miller 2000.) Alaska and Hawaii not included in the 1996 survey so are excluded from analysis.

** Data were obtained from 1991 through 1995 surveys of the Behavioral Risk Factor Surveillance System (BRFSS). Details have been published elsewhere (Siegal et al. 1993; Frazier et al. 1992). Briefly, state health departments conduct monthly telephone surveys of randomly selected persons 18 years old and older. Over the 5-year study period, 22 states asked about household firearms (Table 1]. The median sample size was 2061 , the median response rate was $66.9 \%$, the median proportion of homes with telephones was $95.6 \%$, and the median refusal rate for the firearm section was $2.0 \%$. For states that asked firearm questions in more than 1 year, the most recent data were used.

***The General Social Survey (GSS) is fielded on a regular basis by the University of Chicago's National Opinion Research Center. The GSS utilizes personal interviews with an area probability sample. It has included items on household gun ownership since 1972, and on individual ownership since 1980. The most recent firearms data available from the GSS are for the even-numbered years of the 1990s. The GSS sample is structured so as to be representative of the populations of each of the 9 census regions, but not necessarily of individual states (Davis and Smith 1998). 
Table A4

Firearms Prevalence by State Estimated from HICRC and from FS/S

\section{Rank}

State
Est.

Prevalence Prevalence

From FS/S

(3)

11.59

$\begin{array}{ll}1 & \text { Hawaii } \\ 2 & \text { Massachusetts }\end{array}$

$3 \quad$ New Jersey

4 D.C.

$5 \quad$ New York

$6 \quad$ Rhode Island

$7 \quad$ Connecticut

$8 \quad$ Illinois

9 Delaware

10 California

11 Maryland

12 Minnesota

13 Wisconsin

14 Colorado

15 Pennsylvania

16 Iowa

17 Michigan

18 Ohio

19 New Hampshire

20 Utah
13.08

15.44

20.13

20.19

22.36

25.48

29.39

30.74

33.26

34.97

35.42

35.78

37.70

37.90

38.49

38.96

38.97

39.30

39.61
HICRC

Difference

(4) - (3)

(N)

(4)

(5)

3.08

0.82

16.26

123

$22.48 \quad 2.30$

298

18.75

16

16.67

48

24.86

181

28.57

14

33.66

517

38.27

81

$38.75 \quad 3.33$

80

48.45

97

50.00

62

47.03

219

50.91

55

44.31

167

33.15

184

35.71

28

51.43
$-3.61$

$-8.81$

$-4.53$

$-2.17$

0.39

3.31

3.33

12.67

12.30

9.13

12.42

5.35

$-5.82$

$-3.59$

11.82 


\begin{tabular}{|c|c|c|c|c|}
\hline \multirow[b]{2}{*}{21} & \multirow[b]{2}{*}{ Washington } & \multicolumn{3}{|c|}{35} \\
\hline & & 40.35 & $\begin{array}{c}47.50 \\
80\end{array}$ & 7.15 \\
\hline 22 & Florida & 40.51 & $\begin{array}{c}33.91 \\
230\end{array}$ & -6.59 \\
\hline 23 & Nebraska & 40.85 & $\begin{array}{c}51.72 \\
29\end{array}$ & 10.87 \\
\hline 24 & Maine & 42.12 & $\begin{array}{c}48.00 \\
25\end{array}$ & 5.88 \\
\hline 25 & South Dakota & 42.30 & $\begin{array}{c}66.67 \\
21\end{array}$ & 24.37 \\
\hline 26 & Kansas & 42.88 & $\begin{array}{c}42.55 \\
47\end{array}$ & -0.33 \\
\hline 27 & New Mexico & 42.92 & $\begin{array}{c}46.88 \\
32\end{array}$ & 3.96 \\
\hline 28 & North Dakota & 43.80 & $\begin{array}{c}50.00 \\
14\end{array}$ & 6.20 \\
\hline 29 & Oregon & 43.92 & $\begin{array}{c}57.69 \\
52\end{array}$ & 13.77 \\
\hline 30 & Vermont & 44.40 & $\begin{array}{c}71.43 \\
7\end{array}$ & 27.03 \\
\hline 31 & Indiana & 45.11 & $\begin{array}{c}52.78 \\
108\end{array}$ & 7.67 \\
\hline 32 & Missouri & 45.30 & $\begin{array}{c}50.60 \\
83\end{array}$ & 5.30 \\
\hline 33 & Texas & 46.26 & $\begin{array}{c}49.32 \\
294\end{array}$ & 3.06 \\
\hline 34 & Oklahoma & 47.64 & $\begin{array}{c}55.36 \\
56\end{array}$ & 7.72 \\
\hline 35 & Virginia & 47.92 & $\begin{array}{c}41.38 \\
116\end{array}$ & -6.54 \\
\hline 36 & Nevada & 47.97 & $\begin{array}{c}42.86 \\
21\end{array}$ & -5.12 \\
\hline 37 & Arizona & 48.30 & $\begin{array}{c}46.27 \\
67\end{array}$ & -2.03 \\
\hline 38 & Montana & 48.83 & $\begin{array}{c}76.47 \\
17\end{array}$ & 27.64 \\
\hline 39 & North Carolina & 50.61 & $\begin{array}{c}50.36 \\
139\end{array}$ & -0.25 \\
\hline 40 & Idaho & 50.87 & $\begin{array}{c}76.47 \\
17\end{array}$ & 25.60 \\
\hline 41 & Alaska & 50.91 & & \\
\hline 42 & South Carolina & 51.00 & $\begin{array}{c}47.46 \\
59\end{array}$ & -3.54 \\
\hline 43 & Tennessee & 52.35 & $\begin{array}{c}53.26 \\
92\end{array}$ & 0.91 \\
\hline
\end{tabular}




$\begin{array}{clccc}44 & \text { Arkansas } & 52.51 & 60.00 & 7.49 \\ 45 & \text { Kentucky } & 53.20 & 52.24 & -0.96 \\ & & & 67 & \\ 46 & \text { Georgia } & 53.65 & 54.62 & 0.97 \\ & & & 119 & \\ 47 & \text { West Virginia } & 54.64 & 65.63 & 10.98 \\ 48 & \text { Wyoming } & 54.78 & 87.50 & 32.72 \\ & & & 8 & \\ 49 & \text { Louisiana } & 55.04 & 61.04 & 6.00 \\ & & & 77 & \\ 50 & \text { Alabama } & 57.51 & 57.69 & 0.19 \\ & & & 78 & \\ 51 & \text { Mississippi } & 60.25 & 61.54 & 1.29\end{array}$


Table A5

Validity of two proxies relative to four measures of gun ownership

Panel data, 1980-1998, for 9 Census regions

Regression coefficients and standard errors

Log-log specification

\begin{tabular}{|l|l|l|l|l|}
\hline $\begin{array}{l}\text { Which proxy? } \\
\text { (Year dummies?) }\end{array}$ & $\ln (\% \mathrm{G})$ & $\ln (\% \mathrm{HG})$ & $\ln (\% \mathrm{G}, \mathrm{hh})$ & $\ln (\% \mathrm{GH}, \mathrm{hh})$ \\
\hline $\begin{array}{l}\ln \mathrm{FS} / \mathrm{S} \\
\text { (Yes) }\end{array}$ & $\begin{array}{l}2.352^{\mathrm{a}} \\
(.849)\end{array}$ & $\begin{array}{l}3.130^{\mathrm{a}} \\
(1.102)\end{array}$ & $\begin{array}{l}1.608^{\mathrm{a}} \\
(.569)\end{array}$ & $\begin{array}{l}2.385^{\mathrm{a}} \\
(.821)\end{array}$ \\
\hline $\ln \mathrm{G} \& \mathrm{~A}$ & $.200^{\mathrm{c}}$ & $.301^{\mathrm{c}}$ & .100 & $.201^{\mathrm{c}}$ \\
$($ Yes) & $(.118)$ & $(.154)$ & $(.080)$ & $(.115)$ \\
\hline $\ln \mathrm{FS} / \mathrm{S}$ & $2.154^{\mathrm{a}}$ & $3.264^{\mathrm{a}}$ & $1.276^{\mathrm{a}}$ & $2.386^{\mathrm{a}}$ \\
(No) & $(.687)$ & $(.891)$ & $(.479)$ & $(.665)$ \\
\hline ln G\&A & .139 & $.310^{\mathrm{b}}$ & .026 & $.197^{\mathrm{c}}$ \\
(No) & $(.109)$ & $(.141)$ & $(.075)$ & $(.106)$ \\
\hline
\end{tabular}

a. Significantly different from zero at the $1 \%$ level

b. Significantly different from zero at the $5 \%$ level

c. Significantly different from zero at the $10 \%$ level

Notes: Each cell contains the key coefficient estimate and SE from a different regression. Each regression includes regional dummies; the coefficients are not reported in this table. $\mathrm{N}=126$, annual observations for the following 14 years: 1980-1982, 1984-1985, 1987-1991, 19931994, 1996, and 1998. (The GSS was not fielded during the missing years.) The four measures of gun ownership are the dependent variables in the regressions.

The two proxies for gun ownership are:

- $\mathrm{FS} / \mathrm{S}=\%$ of suicides in region committed with a gun, from Vital Statistics

- G\&A= Subscriptions to Guns\&Ammo per 1000 residents of region from the Audit Bureau of Circulations 
Figure 1

Survey-based state-level household gun ownership vs. FS/S

Figure 2

GSS Region-level Firearm Ownership 


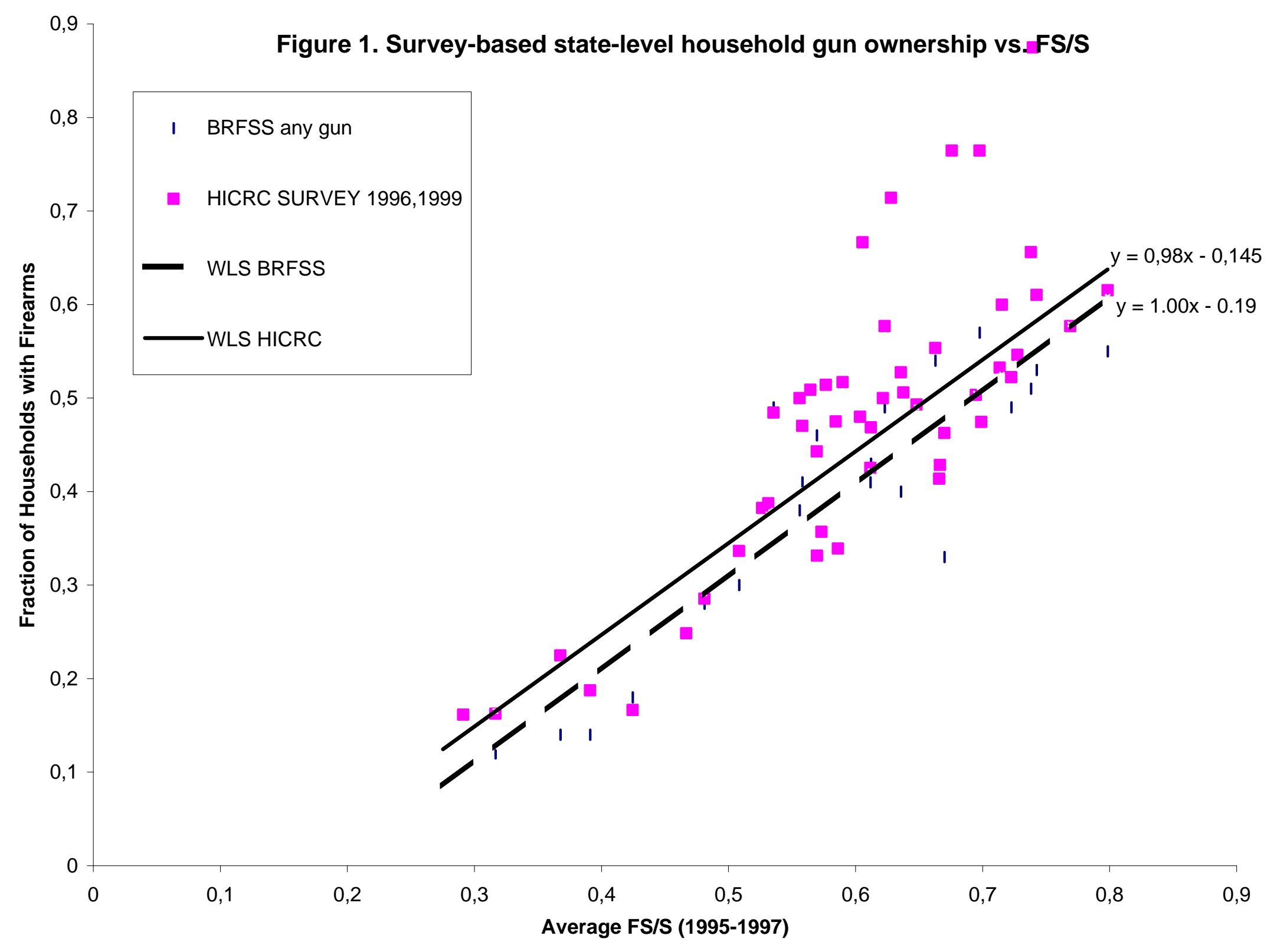


Figure 2. GSS Region-level Firearm Ownership

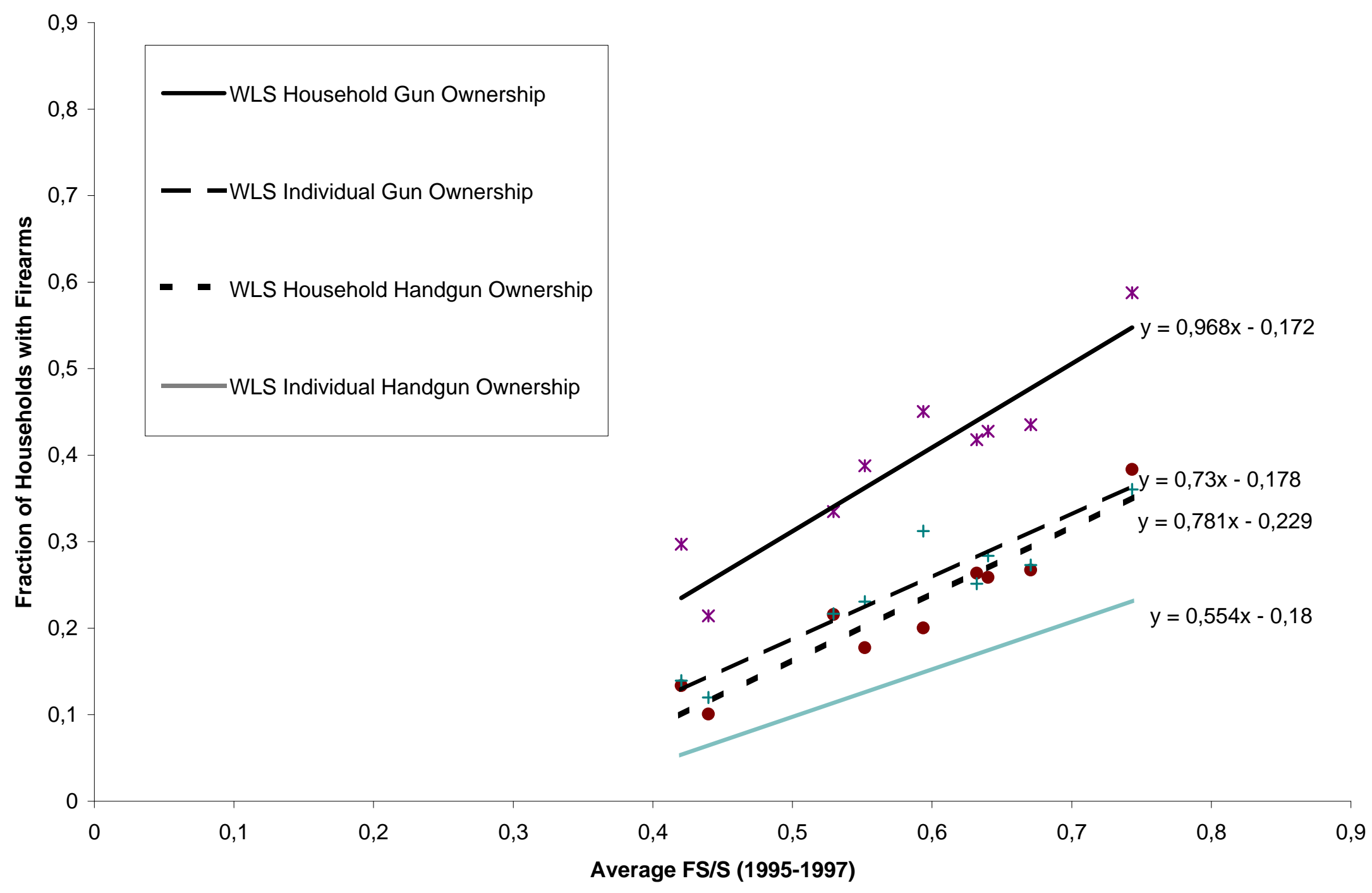

